\title{
TOTAL FIBRINOGEN LEVEL AS A FACTOR OF CARDIOVASCULAR RISK IN PATIENTS WITH HYPERTONIC DISEASE AND OVERWEIGHT
}

\section{L.M. Strilchuk}

\begin{abstract}
Chronic systemic inflammation is a key component of atherogenesis, whereas increased rate of total fibrinogen serves as an independent predictor of ischemic heart disease and additional factor of cardiovascular risk. Our investigation included 53 patients with hypertonic disease and overweight. It was revealed that total fibrinogen rate was proportional to cardiovascular risk, duration of arterial hypertension, severity of anemia, dyslipidemia, hypertrophy and dilatation of left ventricle. Total fibrinogen rate was inversely proportional to systolic function of left ventricle. In patients with increased total fibrinogen more severe right ventricle hypertrophy was revealed.
\end{abstract}

Key words: fibrinogen, systemic inflammation, hypertonic disease, obesity.

Danylo Halytsky National Medical University (Lviv)

Рецензенти: проф. Л.П. Сидорчук

проф. І.А. Плеш
Buk. Med. Herald. - 2015. - Vol. 19, № 2 (74). - P. 189-192

Надійшла до редакції 26.12.2014 року

\section{С Л.М. Стрільчук, 2015 \\ УДК 616.12-005.4+616.12:612.13]-085.254.1 \\ V.K. Tashchuk, O.I. Gulaga, O.S. Polianska, I.S. Popova

REMOTE RESULTS OF USING ALDOSTERONE ANTAGONISTS
IN COMPLEX TREATMENT OF PATIENTS WITH MYOCARDIAL INFARCTION AND HEART FAILURE}

Bukovinian State Medical University (Chernivtsi)

\begin{abstract}
The work presents remote results of using aldosterone in complex treatment of patients with myocardial infarction combined with heart failure. It is shown that after using of eplerenone the authenticity of renewal functional indexes of myocardium becomes higher.
\end{abstract}

Introduction. One of the important issues of treatment of patients with myocardial infarction (MI) and heart failure (HF) is not only an infarction zone stabilization, prevention of progression and death, but also prophylaxis of the changes that can lead to deterioration of the patient's life $[2,3,6]$. This is achieved by reasonable influence on the main mechanisms of development of myocardial infarction and its complications in the early stages of its emergence, stabilization of functional parameters of the cardiovascular system and creation of conditions for the lost functions restoration or optimum adaptation and compensation in the changed conditions of the cardiovascular system functioning $[1,13,15]$.

Material and methods. Study group consisted of 24 people who were hospitalized in the intensive care unit in Chernivtsi regional cardiology clinic with acute Q- MI with signs of acute heart failure Killip I-II class, followed by the formation of CH IIIA stage on a long-term observation (1 year) stage. The diagnosis was verified according to recommendations of the Association of Cardiologists of Ukraine (2012). The average age of patients was $52,1 \pm 3,83$ years. All patients were divided into two clinical groups: for 14 patients, who formed group I, in the basic therapy a nonselective aldosterone an-

(C) V.K. Tashchuk, O.I. Gulaga, O.S. Polianska, I.S. Popova, 2015 192
Key words: myocardial infarction, heart failure, aldosterone, angiotensin-converting factor, von Willebrand factor, remodeling.

tagonist (AA) spironolactone (registration number $\mathrm{T}$ 011953 / $0102.09 .05 \mathrm{~g}$ ) was included with a daily dose of $25 \mathrm{mg}$; the second group consisted of 10 patients who received basic therapy in addition with selective AA eplerenone (registration certificate № UA/3752/0101, UA/3752/01/02 from 09.11.2005g ), the dose was $25 \mathrm{mg}$ per day [8, 17]. The definition of parameters of the functional state of myocardium was performed by using echocardiography in the parasternal and apical positions on the long and short axes with further calculation of cardiac hemodynamics indicators and evaluation of end-diastolic left ventricular size (LVDV), end-systolic size of the left ventricle (LVSV), the thickness of interventricular septum in diastole (STd), the thickness of left ventricular posterior wall in diastole (LVd PWT). According to the formulas of L.E. Teicholz, a set of indicators were calculated: left ventricular enddiastolic volume (EDV), end-systolic volume (ESV), stroke volume (SV), the ejection fraction $(\mathrm{EF})$, left ventricular myocardial mass (MM) and LV myocardial mass index (MMI) [4, 5, 16]. Besides general clinical and instrumental examinations, an enzyme immunoassay for all patients was conducted for the determination of hormone levels such as aldosterone, angiotensin-converting factor (APF), atrial natri- 
uretic peptide (ANP) and von Willebrand factor (vWF) [11,12]. Statistical analysis was performed using Microsoft ${ }^{\circledR}$ Office Excel spread sheets (build 11.5612 .5703 ) and program for statistical processing Statgraphics Plus5.1 Enterprise edition ( $($ Statistical Graphics corp. 2001). We used the theory of chance for the prognosis of the disease, determination of the probability of occurrence of expected events in patients with different output parameters $[14,17]$. A Pvalue $<0.05$ was considered statistically significant.

Results of research and their discussion. After analysis of echocardiographic indicators it was found that patients in both groups showed improvement of myocardial functional parameters (Table 1). It was also identified that DAC increased significantly after using spironolactone, and decreased after the use of eplerenone.

EF while using spironolactone decreased after a year by $5,6 \%$, while using eplerenone increased by $16,1 \%$, what significantly exceeds this rate for those in the first group $(p<0,05)$. SV a year after the treatment was changing differently in both groups.

Thus, in group I indicator decreased by 1,9\%, while in II - grew by $23,2 \%(p<0,01)$. Thickness of PWLVd and IVMd changed not statistically significantly. To assess the effectiveness of the combined treatment with selective and nonselective AA, the chance theory was used to analyze the probability of echocardiography parameter's changes (Table 2). It was found that the use of eplerenone in patients shows a reasonable likelihood of EF increase over $60,05 \pm 5,28 \%$ compared with spironolactone $(\mathrm{t}=2,23, \mathrm{p}<0,05)$, and therefore it is obvious that selective AA have bigger advantage to restore the impaired myocardial contractility after myocardial infarction [9, 12]. However, it is aldosterone, excessive concentration of which was observed in MI, determines morphological and functional disorders, the progression of which is interrupted more effectively by using selective AA.

Estimation of left ventricular hypertrophy regression (LVH) probability a year after hospital treatment revealed different effects of investigated drugs. Thus, while using the Eplerenone, the probability of achieving indicator for LVMM is less $180,24 \pm 15,24$ gr significantly higher than while using Spironolactone $(t=2,10, p<0,05)$. The same regularity is observed for LVMMI - the probability of its decline is probable higher with Eplerenone $(\mathrm{t}=2,75$, $\mathrm{p}<0,01)$. Application of Eplerenone in patients one year after myocardial infarction (MI) showed a significant $\mathrm{LVMM}<180,24 \pm 15,24 \mathrm{gr}$ and probability decrease of ESV less 50,23 $\pm 5,14 \mathrm{ml}(\mathrm{t}=2,101$, $\mathrm{p}<0,05$ ). Influence on the probability of various AA changes of SV is also different - it has been detected a reasonable likelihood of $\mathrm{SV}$ growth over $60,24 \pm 6,73 \mathrm{ml}$ while using Eplerenone in comparasion with Spironolactone $(\mathrm{t}=2,23, \mathrm{p}<0,05)$. In the

Table 1

Echocardiography indicators dynamics in patients with myocardial infarction and heart failure during the treatment

\begin{tabular}{|c|c|c|c|c|c|c|c|}
\hline \multirow{3}{*}{ № } & \multirow{3}{*}{ Indicator } & \multicolumn{3}{|c|}{ Group I } & \multicolumn{3}{|c|}{ Group II } \\
\hline & & $\begin{array}{l}\text { Before } \\
\text { treatment }\end{array}$ & $\begin{array}{l}\text { After treat- } \\
\text { ment }\end{array}$ & $\begin{array}{l}\text { After a } \\
\text { year }\end{array}$ & $\begin{array}{l}\text { Before treat- } \\
\text { ment }\end{array}$ & $\begin{array}{c}\text { After treat- } \\
\text { ment }\end{array}$ & After a year \\
\hline & & 1 & 2 & 3 & 4 & 5 & 6 \\
\hline 1 & $\mathrm{DV}(\mathrm{cm})$ & $4,88 \pm 0,28$ & $4,91 \pm 0,17$ & $4,96 \pm 0,27$ & $4,83 \pm 0,18$ & $5,05 \pm 0,21$ & $5,02 \pm 0,18$ \\
\hline 2 & $\mathrm{SV}(\mathrm{cm})$ & $3,53 \pm 0,21$ & $3,49 \pm 0,18$ & $3,69 \pm 0,10$ & $3,49 \pm 0,15$ & $3,32 \pm 0,26$ & $3,31 \pm 0,16$ \\
\hline 3 & $\mathrm{SSd}(\mathrm{cm})$ & $1,01 \pm 0,08$ & $1,07 \pm 0,05$ & $1,02 \pm 0,02$ & $1,02 \pm 0,06$ & $0,97 \pm 0,08$ & $1,03 \pm 0,04$ \\
\hline 4 & $\begin{array}{c}\text { LVd } \\
\text { PWT(cm) }\end{array}$ & $0,98 \pm 0,09$ & $1,09 \pm 0,05$ & $0,91 \pm 0,12$ & $1,08 \pm 0,06$ & $0,96 \pm 0,11$ & $1,08 \pm 0,04$ \\
\hline 5 & $\begin{array}{r}\text { EDV } \\
(\mathrm{ml})\end{array}$ & $\begin{array}{c}114,90 \pm \\
14,52 \\
\end{array}$ & $\begin{array}{c}114,92 \pm \\
9,49 \\
\end{array}$ & $\begin{array}{c}117,97 \pm \\
15,76 \\
\end{array}$ & $110,51 \pm 9,73$ & $\begin{array}{c}122,89 \pm \\
11,68 \\
\end{array}$ & $120,23 \pm 10,25$ \\
\hline 6 & ESV (ml) & $53,75 \pm 7,28$ & $52,35 \pm 6,70$ & $58,93 \pm 8,11$ & $51,56 \pm 5,14$ & $47,19 \pm 8,66$ & $\begin{array}{c}44,97 \pm 5,59 \\
\text { p-3-6* }\end{array}$ \\
\hline 7 & $\mathrm{SV}(\mathrm{ml})$ & $61,15 \pm 9,33$ & $62,58 \pm 6,88$ & $59,94 \pm 5,68$ & $58,96 \pm 5,72$ & $\begin{array}{c}75,69 \pm 8,36 \\
\text { p-4-5** }\end{array}$ & $\begin{array}{c}76,73 \pm 6,76 \\
\text { p-5-6** }\end{array}$ \\
\hline 8 & $\mathrm{EF}(\%)$ & $53,26 \pm 3,02$ & $55,46 \pm 3,93$ & $50,28 \pm 2,83$ & $53,43 \pm 2,27$ & $\begin{array}{c}62,72 \pm 4,74 \\
\mathrm{p}-3-5^{*} \mathrm{p}-4-5^{*}\end{array}$ & $\begin{array}{c}63,71 \pm 2,87 \\
\text { p-3-6*p-4-6* }\end{array}$ \\
\hline 9 & $\begin{array}{l}\text { LVMM } \\
\text { (gr) }\end{array}$ & $179,91 \pm 21,49$ & $201,73 \pm 17,45$ & $179,09 \pm 13,22$ & $190,31 \pm 16,69$ & $183,51 \pm 22,04$ & $203,31 \pm 15,99$ \\
\hline 10 & $\begin{array}{l}\text { LVMMI } \\
\left(\mathrm{gr} / \mathrm{m}^{2}\right)\end{array}$ & $91,27 \pm 10,30$ & $102,74 \pm 9,27$ & $89,19 \pm 2,55$ & $95,25 \pm 8,59$ & $93,43 \pm 10,75$ & $\begin{array}{c}111,49 \pm 5,78 \\
\text { p-1-6* } \\
\text { p-3-6* }\end{array}$ \\
\hline
\end{tabular}

Note: $*$ odds ratio - $\mathrm{p}<0.05 ; * *-<0.01 ; * * *-<0.001$ (shown only statistically probable deviations) 
Table 2

The influence of eplerenone / spironolactone on echocardiography indicators changes in patients with myocardial infarction one year after hospital treatment

\begin{tabular}{|c|c|c|c|}
\hline № & Indicator & $\mathrm{t}$ & $\mathrm{P}$ \\
\hline 1 & The Ejection fraction $(\%)>60,05 \pm 5,28 / \leq 60,05 \pm 5,28$ & 2,23 & $<0,05$ \\
\hline 2 & $\mathrm{LVMM}(\mathrm{gr})<180,24 \pm 15,24 / \geq 180,24 \pm 15,24$ & 2,10 & $<0,05$ \\
\hline 3 & $\mathrm{LVMMI}\left(\mathrm{gr} / \mathrm{m}^{2}\right)<95,22 \pm 6,87 / \geq 95,22 \pm 6,87$ & 2,75 & $<0,01$ \\
\hline 4 & $\mathrm{EDV}(\mathrm{ml})>120,74 \pm 11,23 / \leq 120,74 \pm 11,23$ & 2,10 & $<0,05$ \\
\hline 5 & $\mathrm{ESV}(\mathrm{ml})<50,23 \pm 5,14 / \geq 50,23 \pm 5,14$ & 2,10 & $<0,05$ \\
\hline 6 & $\mathrm{SV}(\mathrm{ml})>60,24 \pm 6,73 / \leq 60,24 \pm 6,73$ & 2,23 & $<0,05$ \\
\hline 7 & $\mathrm{TLVdPWT}(\mathrm{cm})<1,09 \pm 0,03 / \geq 1,09 \pm 0,03$ & 1,49 & $>0,05$ \\
\hline 8 & $\mathrm{SSd}(\mathrm{cm})<1,01 \pm 0,05 / \geq 1,01 \pm 0,05$ & 0,14 & $>0,05$ \\
\hline
\end{tabular}

Table 3

Dynamics of neurohumoral regulation indicators in patients with myocardial infarction and heart failure in a year

\begin{tabular}{|c|c|c|c|c|c|c|}
\hline \multirow{3}{*}{ № } & \multirow{3}{*}{ Indicator } & Control & \multicolumn{2}{|c|}{ Group I } & \multicolumn{2}{|c|}{ Group II } \\
\hline & & \multirow[b]{2}{*}{1} & 2 & 3 & 4 & 5 \\
\hline & & & $\begin{array}{l}\text { Before treat- } \\
\text { ment }\end{array}$ & In a year & $\begin{array}{l}\text { Before treat- } \\
\text { ment }\end{array}$ & In a year \\
\hline 1 & Aldosterone (pmole/l) & $152,34 \pm 16,24$ & $\begin{array}{c}239,03 \pm 11,45 \\
\text { p-1-2-** }\end{array}$ & $\begin{array}{c}198,74 \pm 21,44 \\
\text { p-2-3-* }\end{array}$ & $\begin{array}{c}242,11 \pm 10,72 \\
\text { p-1-4-** }\end{array}$ & $\begin{array}{c}158- \\
, 54 \pm 12,01 \\
\mathrm{p}-4-5-* * *\end{array}$ \\
\hline 2 & $\begin{array}{l}\text { Angiotenzinconverting } \\
\text { factor }(\mathrm{mcmole} / \mathrm{min} / \mathrm{l})\end{array}$ & $51,98 \pm 3,45$ & $\begin{array}{l}70,24 \pm 2,61 \\
\text { p-1-2-** }\end{array}$ & $\begin{array}{l}57,52 \pm 3,18 \\
\text { p-2-3-* }\end{array}$ & $\begin{array}{c}71,65 \pm 3,56 \\
\text { p-1-4-* }\end{array}$ & $\begin{array}{c}49,44 \pm 2,56 \\
\text { p-4-5-** }\end{array}$ \\
\hline 3 & Natriuretic peptide (pgr/ml) & $31,82 \pm 7,60$ & $\begin{array}{l}56,97 \pm 6,42 \\
\text { p-1-2-* }\end{array}$ & $\begin{array}{c}24,37 \pm 5,72 \\
\text { p-2-3-** }\end{array}$ & $\begin{array}{l}58,77 \pm 7,48 \\
\text { p-1-4-* }\end{array}$ & $\begin{array}{l}11,19 \pm 4,73 \\
\text { p-4-5-*** }\end{array}$ \\
\hline 4 & vWF (mgr/l) & $0,89 \pm 0,06$ & $\begin{array}{l}1,15 \pm 0,03 \\
\text { p-1-2-** }\end{array}$ & $\begin{array}{c}1,05 \pm 0,03 \\
\text { p-2-3-* }\end{array}$ & $\begin{array}{l}1,18 \pm 0,09 \\
\text { p-1-4-** }\end{array}$ & $\begin{array}{l}0,68 \pm 0,08 \\
\text { p-4-5-*** }\end{array}$ \\
\hline
\end{tabular}

Note: $*_{-}$the coefficient of probability $-\mathrm{p}<0,05 ; * *{ }_{-}<0,01 ; * * *_{-}<0,001$ (shown only statistically probable deviations)

Table 4

Influence of Eplerenone/ Spironolactone on changes of neurohumoral messenger's parameters in patients with myocardial infarction and heart failure a year after hospital treatment

\begin{tabular}{|c|c|c|c|}
\hline № & Indicator & $\mathrm{t}$ & $\mathrm{p}$ \\
\hline 1 & Aldosterone $(\mathrm{pmole} / \mathrm{l}) \leq 149,36 \pm 10,26 />149,36 \pm 10,26$ & 2,10 & $<0,05$ \\
\hline 2 & $\begin{array}{c}\text { Angiotenzinconverting factor }(\mathrm{mcmole} / \mathrm{min} / \mathrm{l}) \\
\leq 50,22 \pm 2,57 />50,22 \pm 2,57\end{array}$ & 2,29 & $<0,05$ \\
\hline 3 & Natriuretic peptide $(\mathrm{pgr} / \mathrm{ml}) \leq 28,62 \pm 5,19 />28,62 \pm 5,19$ & 2,75 & $<0,01$ \\
\hline 4 & $\mathrm{vWF}(\mathrm{gr} / \mathrm{l}) \leq 0,54 \pm 0,03 />0,541 \pm 0,03$ & 1,49 & $>0,05$ \\
\hline
\end{tabular}

analysis of neurohumoral messengers level which are actively involved in the regulation of cardiovascular activity and realization of compensatory-adaptive mechanisms, it was found (Table 3) that the dynamics of hormones in both groups is aimed at significant reduction.

The analysis of aldosterone concentration in blood plasma found that its content decreased significantly in both groups (Table 4) after a year, although more expressed in patients treated with Eplerenone $(p<0,01)$. Prolonged effect of aldosterone concentration reduction, in our opinion, is due to the fact that timely and effective blocking of the hor- mone excessive synthesis and the prevention of its action on receptors makes it possible to interrupt the ways of its synthesis initiation, implementation damaging effect on the cardiovascular system, as well as break the pathological range of mutual hormones stimulation. A proof of this is the dynamic of ACE concentration - the main initiator of aldosterone synthesis, which decreased significantly in both groups of patients in a year, but more expressed and reliable in patients treated with Eplerenone.

Decrease of aldosterone concentration in blood plasma during this period was also accompanied by a decrease of NUP level which provides the opposite 
effect - it stimulates natriuresis and decreases blood volume. Typically, the concentration of NUP in patients of Group II is almost two times lower than in Group I ( $p<0.001)$. Despite the fact that the synthesis of NUP is initiated by irritation of atrium baroand chemoreceptors with rise of circulating blood volume, increase of pressure in the atrial cavities with preload growth, such concentration dynamics of this neuromessenger and humoral regulator of water and electrolyte balance is a confirmation of reducement of heart failure progression. This has been achieved in patients by eliminating the pathogenic effect of the excessive aldosterone concentration growth by the use of the selective aldosterone antagonist [12]. Concentrations of vWF - one of the most important regulators of the coagulation homeostasis and markers of endothelial dysfunction [7, 10], also decreased significantly, and more expressed - in patients treated with Eplerenone. Statistical analysis of the effectiveness of AA using chance theory suggests that in patients in the combined treatment with myocardial infarction with heart failure was included eplerenone, there is a higher probability of reducing the level of aldosterone in physiological parameters compared with patients treated with spironolactone $(t=2,10 ; p<0,05)$. Chances of a significant reduction in such patients, the concentration of ACE also significantly higher $(t=2,29, p<0,05)$, as the probability of a significant reduction in the concentration of ANP $(t=2,75, p<0,01)$. Statistical analysis of the effectiveness of AA using chance theory suggests that in patients who underwent combined treatment of myocardial infarction with heart failure, including Eplerenone, there is a higher probability of reducing the aldosterone level in physiological parameters compared with patients treated with Spironolactone $(t=2,10 ; p<0,05)$. Chances of ACF significant reduction in such patients are also significantly higher $(t=2,29, p<0,05)$, as the probability of a significant reduction in the concentration of NUP $(t=2,75$, $\mathrm{p}<0,01)$. Thus, studies have shown a higher efficiency of the selective AA Eplerenone in the aspect of improvement in dynamics of neurohormonal messengers and functional state of the myocardium in the remote follow-up period in patients with MI treatment.

\section{Conclusions}

1. Coronary incident in the form of myocardial infarction with heart failure associated with activation of neurohumoral messengers having a substantial effect on the functional state of the myocardium even in remote periods of observation.

2. Use of aldosterone antagonists in the treatment of patients with myocardial infarction with heart failure in a year helps to reduce the activity of neurohumoral messengers, to recover the functional state of the myocardium parameters; and the more effective selective aldosterone antagonist is Eplerenone.

3. It was found that the probability of myocardial contractility and cardiac pump function improvement, reduction of myocardial mass during the year using Eplerenone in patients with acute myocardial infarction.

Prospect of further researches. There will be an investigational level of vazopresin at the heart attack of myocardium and correlation from vazoactive hormones.

\section{References}

1. Aldosterone, mortality, and acute ischaemic events in coronary artery disease patients outside the setting of acute myocardial infarction or heart failure / F. Ivanes, S.Susen, F. Mouquet [et al.] // Eur. Heart J. - 2012. Vol. 33, № 2. - P. 191-202.

2. Bauersachs J. Pre-clinical data on involvement of mineralocorticoid receptor activation in healing and remodeling post-myocardial infarction / J. Bauersachs, D. Fraccarolo // Eur.Heart J. Suppl. - 2012. - Vol. 13. Suppl.B. - P. 10-14.

3. Braunwald E. The Thrombolysis in Myocardial Infarction (TIMI) Study Group experience / E. Braunwald, M.S. Sabatine // J. Thorac Cardiovasc. Surg. - 2012. Vol. 144, № 4. - P. 762-770.

4. Braunwald E. The rise of cardiovascular medicine / E. Braunwald // Eur. Heart J. - 2012. - Vol. 33, № 7 . P. 838-845.

5. Cardiovascular mortality and heart failure risk score for patients after ST-segment elevation acute myocardial infarction treated with primary percutaneous coronary intervention (Data from the Leiden MISSION! Infarct Registry) / M.L. Antoni, G.E. Hoogslag, H. Boden [et al.] // Am. J. Cardiol. - 2012. - Vol. 109, № 2. P. 187-194.

6. Declining in-hospital mortality and increasing heart failure incidence in elderly patients with first myocardial infarction / J. Ezekowitz, P. Kaul, J. Bakal [et al.] // J. Amer. Coll. Cardiology. - 2012. - Vol. 53, № 1. P. 13-20.

7. Determinants and consequences of renal function variations with aldosterone blocker therapy in heart failure patients after myocardial infarction: insights from the Eplerenone Post-Acute Myocardial Infarction Heart Failure Efficacy and Survival Study / P. Rossignol, J.G. Cleland, S. Bhandari [et al.] // Circulation. - 2012. Vol. 125, № 2. - P. 271-279.

8. Eplerenone in patients with systolic heart failure and mild symptoms / F. Zannad, J. McMurray, H. Krum [at al.] // N. Engl. J. Med. - 2011. - Vol. 1, № 364. - P. 11-21.

9. Eplerenone in patients with systolic heart failure and mild symptoms: analysis of repeat hospitalizations / J.K. Rogers, J.J. McMurray, S.J. Pocock [et al.] // Circulation. - 2012. - Vol. 126, № 19. - P. 2317-2323.

10. Eplerenone survival benefits in heart failure patients postmyocardial infarction are independent from its diuretic and potassium-sparing effects. Insights from an EPHESUS (Eplerenone Post-Acute Myocardial Infarction Heart Failure Efficacy and Survival Study) substudy / P. Rossignol, J. Ménard, R. Fay / J. Am. Coll. Cardiol. - 2011. Vol. 58, № 19. - P. 1958-1966.

11. EURObservational Research programme: The Heart Failure Pilot Survey (ESC-HF Pilot) / A.P. Maggioni, U. Dahlstro, G. Filippatos [et al.] // Eur. J. Heart Fail. 2010. - Vol. 12. - P. 1076-1084.

12. ESC guidelines for the diagnosis and treatment of acute and chronic heart failure 2012: The Task Force for the Diagnosis and Treatment of Acute and Chronic Heart Failure 2012 of the European Society of Cardiology / J.J. McMurray, S. Adamopoulos, S.D. Anker [et al.] // Eur. Heart J. - 2012. - Vol. 33. - P. 787-1847.

13. Giugliano R.P. The year in non-ST-segment elevation acute coronary syndrome / R.P. Giugliano, E. Braunwald // J. Am. Coll. Cardiol. - 2011. - Vol. 58, № 22. P. 2342-2354. 
14. Heart failure in acute myocardial infarction: a comparison between patients with or without heart failure criteria from the FAST-MI registry / Y.Juillière, J.P. Cambou, V Bataille [et al.] // Rev. Esp. Cardiol. (Engl). - 2012. Vol. 65, № 4. - P. 326-333.

15. Introduction of High-sensitivity Troponin Assays: Impact on Myocardial Infarction Incidence and Prognosis / T. Reichlin, R. Twerenbold, M. Reiter [et al.] // Am. J. Med. - 2012. - Vol. 125, № 12. - P. 1205-1213.
16. McMuray, J. ESC Guideilnes for the diagnosis and treatment of acute and chronic heart failure 2012 / J. McMuray, S. Adaumopolous // Europ.Heart J. - 2012. - № 33. P. 1787-1847.

17. Messaoudi S. Aldosterone and the mineralocorticoid receptor / S. Messaoudi, F. Jaisser // Eur. Heart J. Suppl. 2012. - Vol. 13. - Suppl.B. - P. 4-9.

\section{ОТДАЛЕННЫЕ РЕЗУЛЬТАТЫ ДЛИТЕЛЬНОГО ИСПОЛЬЗОВАНИЯ АНТАГОНИСТОВ АЛЬДОСТЕРОНА В КОМПЛЕКСНОМ ЛЕЧЕНИИ БОЛЬНЫХ ИНФАРКТОМ МИОКАРДА С СЕРДЕЧНОЙ НЕДОСТАТОЧНОСТЬЮ}

\section{В.К. Ташук, О.И. Гулага, О.С. Полянская, И.С. Попова}

Резюме. В работе приведены отдаленные результаты использования антагонистов альдостерона в комплексном лечении больных инфарктом миокарда с сердечной недостаточностью. Показано, что при использовании эплеренона более высокая вероятность восстановления функциональных показателей миокарда.

Ключевые слова: инфаркт миокарда, сердечная недостаточность, альдостерон, ангиотензин-превращающий фермент, предсердный натрийуретический пептид, фактор Виллебранда, ремоделирование.

\section{ВІДДАЛЕНІ РЕЗУЛЬТАТИ ТРИВАЛОГО ВИКОРИСТАННЯ АНТАГОНІСТІВ АЛЬДОСТЕРОНУ В КОМПЛЕКСНОМУ ЛІКУВАННІ ХВОРИХ НА ІНФАРКТ МІОКАРДА 3 СЕРЦЕВОЮ НЕДОСТАТНІСТЮ}

\section{В.К. Тащук, О.І. Гулага, О.С. Полянська, І.С. Попова}

Резюме. У роботі наведені віддалені результати використання антагоністів альдостерону в комплексному лікуванні хворих на інфаркт міокарда з серцевою недостатністю. Показано, что при використанні еплеренону більш висока вірогідність відновлення функціональних показників міокарда.

Ключові слова: інфаркт міокарда, серцева недостатність, альдостерон, ангіотензин-перетворювальний фермент, передсердний натрійуретичний пептид, фактор Віллебранда, ремоделювання.

Буковинський державний медичний університет (м. Чернівці)

Рецензент - проф. Т.О. Ілащук
Buk. Med. Herald. - 2015. - Vol. 19, № 2 (74). - P. 192-196

Надійшла до редакції 06.01.2015 року

(C) V.K. Tashchuk, O.I. Gulaga, O.S. Polianska, I.S. Popova, 2015 